\title{
Effects of substratum and conspecific adults on the development and metamorphosis of Acanthocyclus hassleri (Brachyura: Bellidae) megalopae under laboratory conditions
}

Efecto del sustrato y adultos conespecíficos sobre el desarrollo y metamorfosis de megalopas de Acanthocyclus hassleri (Brachyura: Bellidae) bajo condiciones de laboratorio

\author{
Erwin M. Barría ${ }^{1}$, Mauricio A. Pradenas ${ }^{1}$ and Carlos G. Jara ${ }^{1}$
}

${ }^{1}$ Instituto de Zoología, Universidad Austral de Chile, Casilla 567, Valdivia, Chile. erwinbarria@gmail.com

\begin{abstract}
Resumen.- El éxito en la transición pélago-bentónica del meroplancton depende en gran medida de las señales ambientales que induzcan el asentamiento y la metamorfosis. Acanthocyclus hassleri interactúa con las colonias sésiles de Perumytilus purpuratus y Phragmatopoma virgini desde etapas ontogenéticas tempranas; por ello planteamos que el desarrollo y la metamorfosis de la megalopa de A. hassleri son influenciadas por la presencia de estas especies y/ o adultos conespecíficos. Evaluamos el tiempo de desarrollo, frecuencia de metamorfoseados y supervivencia de megalopas en cultivo, usando como sustratos P. purpuratus, P. virgini, conchas y habitáculos vacíos de ambas especies, un tratamiento con agua de adultos conespecíficos y un control sin estímulo. El desarrollo megalopal fue significativamente más corto en los tratamientos con sustrato. En promedio, el retardo de la metamorfosis fue de cuatro días. La mortalidad fue levemente menor en los tratamientos sin sustrato, pero sin diferencias significativas. El desarrollo de la megalopa está influenciado por las condiciones físicas del sustrato, no así la supervivencia, ya que la larva metamorfosea espontáneamente en ausencia de estímulo. El retardo de la metamorfosis es menor que en otras especies; además, la temperatura de cultivo fue menor a su óptimo térmico, por lo que este umbral puede ser aún mas estrecho en condiciones cercanas al óptimo. Comparando nuestros resultados con estudios en especies estuarinas y gregarias, se sugiere que la naturaleza del estímulo y la respuesta larval puede depender de la densidad poblacional adulta y la energía involucrada en la hidrodinámica del hábitat.
\end{abstract}

Palabras clave: Decapoda, Iarva, inducción, señal ambiental, transición pélago-bentónica

\begin{abstract}
Success in the pelagic-benthic transition of the meroplankton depends to a great extent on the environmental signals that induce the settlement and metamorphosis. Acanthocyclus hassleri interacts with sessile colonies of Perumytilus purpuratus and Phragmatopoma virgini from its early ontogenetic stages onwards. Thus, we propose that megalopal development and metamorphosis of A. hassleri are influenced by the presence of such species and/ or conspecific adults. We evaluated the development time, frequency of metamorphosis, and survival of megalopae in culture, using as substrates P. purpuratus, P. virgini, empty shells and dwellings of both species, a treatment with water exposed to conespecific adults, and a control experiment without stimulus. Megalopal development was significantly shorter in treatments with a substrate. The average delay in metamorphosis was four days. Mortality was slightly lower in treatments without a substrate, but this was not statistically significant. Megalopal development was influenced by the physical conditions of the substrate, but not the survival because the larvae metamorphosed spontaneously in the absence of stimulation. Delay in metamorphosis was lower than in other species; furthermore, the temperature of the culture was lower than the thermal optimum, thus it is likely that this threshold would be even narrower under conditions closer to the optimum. Comparing our results with studies in estuarine and gregarious species, we suggested that the nature of stimulus and larval response could depend on the population density of the adults and the energy involved in the hydrodynamics of habitat.
\end{abstract}

Key words: Decapoda, larvae, induction, environmental cue, pelagic-benthic transition

\section{INTRODUCTION}

Benthic marine invertebrates with meroplanktonic life cycles are characterized by to have pelagic larval phases followed by a benthic adult stage. Transition between both environments involves three processes closely related and widely discussed, i.e., settlement, metamorphosis, and recruitment (Chia 1978, Pechenik 2006). Settlement 
includes behavioral patterns of sinking through the water column and the search for certain features on the substrate that induce the morphological, physiological and metabolic changes involved in metamorphosis and adaptation to new habitat (Hadfield 1986, Rodríguez et al. 1993). On the other hand, recruitment is defined in simple terms as the incorporation of new members into a population by reproduction or immigration (Lincoln et al. 1998). However, for others this concept is related to survival and/ or the period required for newly settled individuals reach a certain size (e.g., Roegner 1991). Despite the conceptual variations, it is possible to generalize that the settlement and metamorphosis are explained by mechanisms operating at the individual level (e.g., behavior patterns, physiological responses), while recruitment depends on density-dependent processes arising from population dynamics (Hurlbut 1991, Anger 2001, Pardo et al. 2007).

Throughout larval ontogeny, there are different critical points in development that are controlled by the interaction between extrinsic factors such as temperature, salinity, food availability, and intrinsic factors such as endocrine regulation or the genetic basis of various organismic processes (Anger 1987, Olson \& Olson 1989). In particular, in the settlement and metamorphosis processes there are active interactions between the individual and the environment involved. Premetamorphic stages of most benthic marine invertebrates are characterized by a specific adaptive condition known as metamorphic competence or a competent larval stage (Hadfield 2000). In this phase, different environmental features can act as signals that the larvae are able to detect and associate with information on habitat quality necessary for the development of postmetamorphic juveniles (Hadfield et al. 2001). In this context, there occur two types of mutually exclusive responses: (a) the environmental cues captured by the competent larva induce the sequence of events involved in metamorphosis, or (b) in the absence of an appropriate environmental cue, the competent larvae delay metamorphosis within a certain time threshold, after which spontaneous metamorphosis or the death of the competent larva occurs (Pawlik 1998, Pechenik et al. 1998).

The larval stage that precedes the metamorphosis and transformation to first juvenile in many decapod crustaceans is the megalopa (Williamson 1969). Morphofunctionally, the megalopa is able to swim in the water column using its pleopods and walk on the bottom using its pereiopods. Thus, the megalopa is responsible for the pelagic-benthic transition and consequently, it must achieve metamorphic competence, before passing through settlement and metamorphosis (McConaugha 1992, Anger 2001). Several studies have reported that both the duration and survival of megalopa stage as body size and growth of postmetamorphic individuals may be strongly influenced by the presence or absence of physical and/or chemical cues from the habitat of the adult population. Many stimuli have been experimentally tested to determine if they function as inducers of settlement and metamorphosis in decapod megalopae. For example, the manipulation of variables associated with the environmental dynamics of estuaries, such as reducing salinity or the presence of humic acid accelerated the metamorphosis in the crab Callinectes sapidus (Forward et al. 1997). In addition, different types of substrate also generate variability in the development time of megalopae and postmetamorphic survival in Uca pugilator and Neohelice (= Chasmagnathus) granulata (Christy 1989, Gebauer et al. 1998). On the other hand, the presence of adults and/or excretion products from conspecifics or phylogenetically related individuals have been reported as potential metamorphic inducers in $U$ pugnax, N. granulata and Sesarma curacaoense amongst other species (O’Connor \& Gregg 1998, Gebauer et al. 1998, 2002, 2003).

The Acanthocyclus genus is a taxon of brachyuran crabs composed of three species, A. hassleri, A. albatrossis, and A. gayi which inhabit the rocky intertidal zone along the majority of the of Chilean coast (Zagal et al. 2001). Of the three species, A. hassleri has the widest latitudinal distribution and higher population abundances on the coast of the Valdivia province (Retamal 1981, Carrasco \& Zamorano 2000). This species is also an important regulator of the population and topographical structure of the most abundant sessile organisms of the intertidal of southern-central Chile.

The regulated species include the mussel Perumytilus purpuratus and the reef-forming sabellarid polychaete Phragmathopoma virgini (Castilla et al. 1989, Zamorano et al. 1995), both of which also play important ecological roles as bioengineers and facilitators of microhabitats for a significant portion of the invertebrate community in these areas (Sepúlveda et al. 2003, Prado \& Castilla 2006). Taking account that Acanthocyclus species recruit to the intertidal zone, maintaining a close interaction with the colonies of $P$. purpuratus and $P$. virgini from early postlarval ontogeny (Jara \& Moreno 1983, Navarrete et al. 2008), and that A. hassleri have a relatively higher density with respect of their congeneric species, it is plausible that both the colonial species and/or conspecifics adults may act as potential promoters of settlement and 
metamorphosis for this crab. We hypothesized that exposure to potential inducers of settlement and metamorphosis, present on the substrate or dissolved in the water, generate different effects on the development and survival of A. hassleri megalopae. Therefore, the objective of this study was to compare the development time and success of the metamorphosis of A. hassleri megalopae by exposing them experimentally to products of the excretion of conspecific adults and the main biogenic substrates with which this species interacts on the southerncentral Chilean coast.

\section{Material AND MEthods}

Ovigerous females of Acanthocyclus hassleri were collected by hand at low tide from the rocky intertidal zone at Pichicullín in the Valdivia province, south-central Chile $\left(39^{\circ} 25^{\prime} \mathrm{S}, 73^{\circ} 13^{\prime} \mathrm{W}\right)$. The individuals were transported live to the Institute of Zoology of the Universidad Austral de Chile. Females carrying eggs at an advanced stage of embryonic developmental were selected. This was determined primarily by the presence of eyespots, development of the abdomen and appendages, the observation of internal movements, heartbeat, and low percentage of yolk remaining (Wehrtmann \& López 2003), The selected females were maintained in glass aquaria in $500 \mathrm{ml}$ of filtered seawater (pore size $1 \mu \mathrm{m}$ and UV irradiated) with constant aeration until the larvae hatched. The maintenance of ovigerous females, the cultivation of zoea larvae and the experiments with megalopae were all conducted under temperature, salinity, and photoperiod conditions of $12^{\circ} \mathrm{C}, 33 \pm 1 \%$, and $12: 12 \mathrm{~h}$ light:dark, respectively.

Five females began to release larvae $72 \mathrm{~h}$ after their arrival in the laboratory. Zoea cultures were started with larvae that were produced on the second day after hatching began. The cultures were maintained in $500 \mathrm{ml}$ plastic containers each holding $400 \mathrm{ml}$ seawater, with an initial population of 100 zoeae per container. Seawater used for culturing was passed through a series of filters of $10 \mu \mathrm{m}$, $5 \mu \mathrm{m}, 1 \mu \mathrm{m}, 0.5 \mu \mathrm{m}$ and ultraviolet radiation. The culture seawater and vessels were changed daily. Larvae were fed daily ad libitum with recently hatched Artemia sp. nauplii. Under these conditions we reared 1500 zoea from five females randomly distributed across 15 containers.

To assess how the development of the megalopa and metamorphosis success rates of $A$. hassleri were influenced by different environmental cues, 540 newly molted megalopae were distributed across six experimental treatments: 1) living individuals of Perumytilus purpuratus (Pp); 2) living individuals of Phragmatopoma virgini (Pv); 3) empty shells of P. purpuratus (s-Pp); 4) empty dwellings of $P$. virgini (d-Pv); 5) water previously incubated with conspecific adults (CA); and 6) a control treatment consisting of sea water filtered and then sterilized with ultraviolet radiation (Co). In each experimental treatment we used nine replicates, each consisting of a $350 \mathrm{ml}$ plastic bowl containing the specified substrate and 10 newly moulted megalopae. In treatments Pp and Pv, aggregations of 12 individuals of either $P$. purpuratus or $P$. virgini were selected. Each aggregation was carefully cleaned under a Wild M3Z stereomicroscope ensuring the total removal of epibionts. For treatments s-Pp and d-Pv, aggregations of a similar number of individuals were boiled in distilled water and all the soft tissues removed.

The duration of the megalopal stage was measured as the period of time (in days) between the moult to megalopa and the metamorphosis to first juvenile. In addition, for each treatment, we calculated the cumulative frequency of metamorphosis in time. With this information, and following the analysis developed by Gebauer et al. (1998), we compared the percentage of individuals metamorphosed at two specific points during the experiments: 1) when metamorphosis was achieved by $50 \%$ of megalopae belonging to a treatment with a shorter development time, and 2) when metamorphosis was achieved by $50 \%$ of the individuals in the treatment with the highest megalopal development time. Finally, metamorphic success was reflected by megalopal survival, defined as the percentage of individuals that achieved metamorphosis.

All data were subjected to the Shapiro-Wilks normality test (Gill 1978) and the Brown-Forsythe homoscedasticity test (Brown \& Forsythe 1974). If the data did not meet the assumptions required for parametric hypothesis testing, a logarithmic transformation of megalopal development time and an angular transformation for all percentage data were performed. If data were parametric, we applied an oneway ANOVA with a posteriori Tuckey test of least significant difference; otherwise, a nonparametric KruskalWallis hypothesis test was performed (Zar 1999).

\section{Results}

Larval development of A. hassleri consists of four zoeal phases and one megalopal stage. The total zoeal stage lasted on average $72 \pm 3.6$ days, with a survival of approximately $79 \%$ at the end of the Zoea IV stage. Therefore, from the initial population (1500 newly hatched 


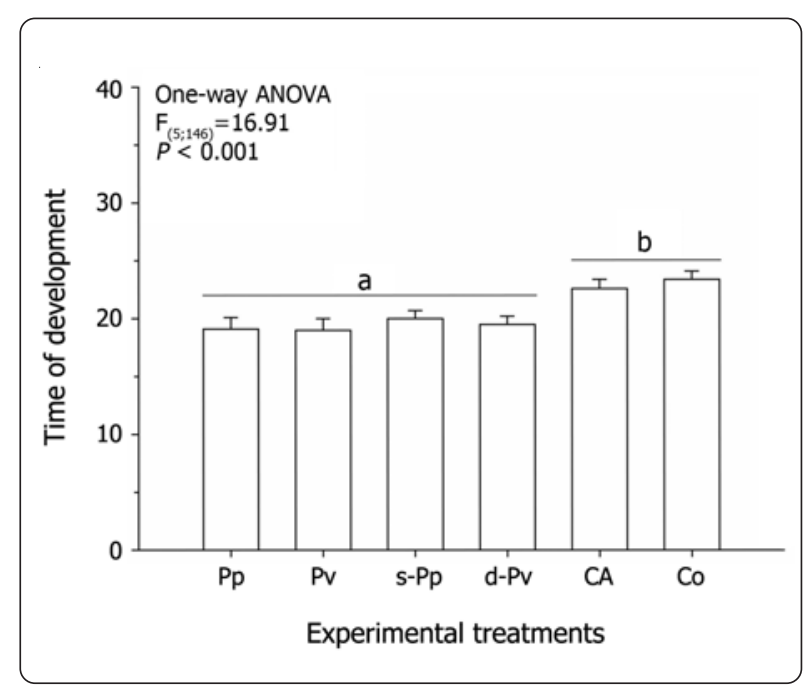

Figure 1. Development time (mean \pm standard deviation) of $\mathbf{A}$. hassleri megalopae exposed to different treatments designed to induce metamorphosis (Pp: P. purpuratus, Pv: P. virgini, sPp: empty shells of $P$. purpuratus, d-PV: empty dwellings of $P$. virgini, CA: water incubated with conespecific adults, and Co: control treatment) Lower-case letters indicate statistically significant differences / Tiempo de desarrollo (promedio \pm desviación estándar) en megalopas de A. hassleri expuestas a diferentes tratamientos de inducción a la metamorfosis. (Pp: P. purpuratus, Pv: P. virgini, s-Pp: conchas vacías de P. purpuratus, d-Pv: habitáculos vacíos de P. virgini, CA: agua incubada con adultos conespecíficos y Co: tratamiento control). Las letras minúsculas indican diferencias estadísticamente significativas

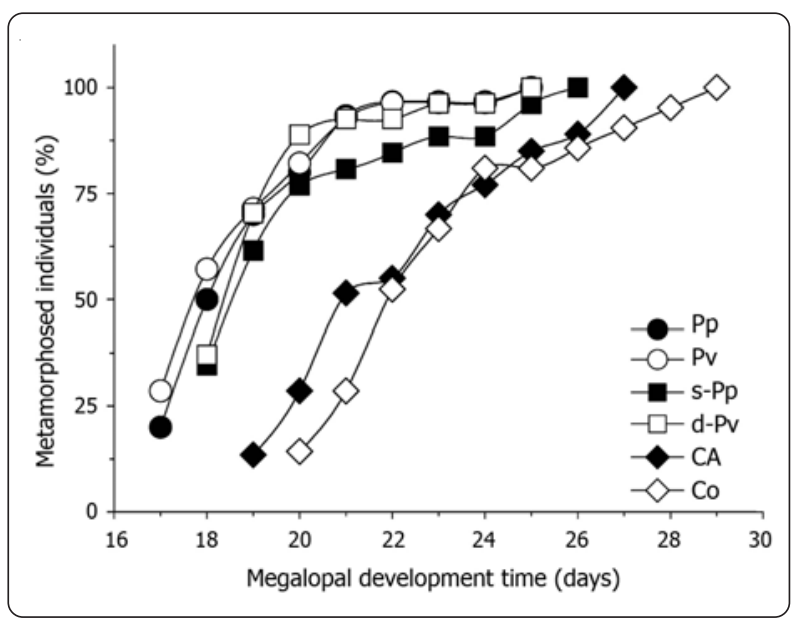

Figure 2. Cumulative percentage curves for the time of metamorphosed individuals of $A$. hassleri experimentally subjected to different treatments designed to induce metamorphosis. Abbreviations as in Fig. 1 / Curvas de porcentaje acumulado en el tiempo de individuos metamorfoseados de A. hassleri sometidos experimentalmente a diferentes tratamientos de inducción a la metamorfosis. Abreviaciones como en la Fig. 1

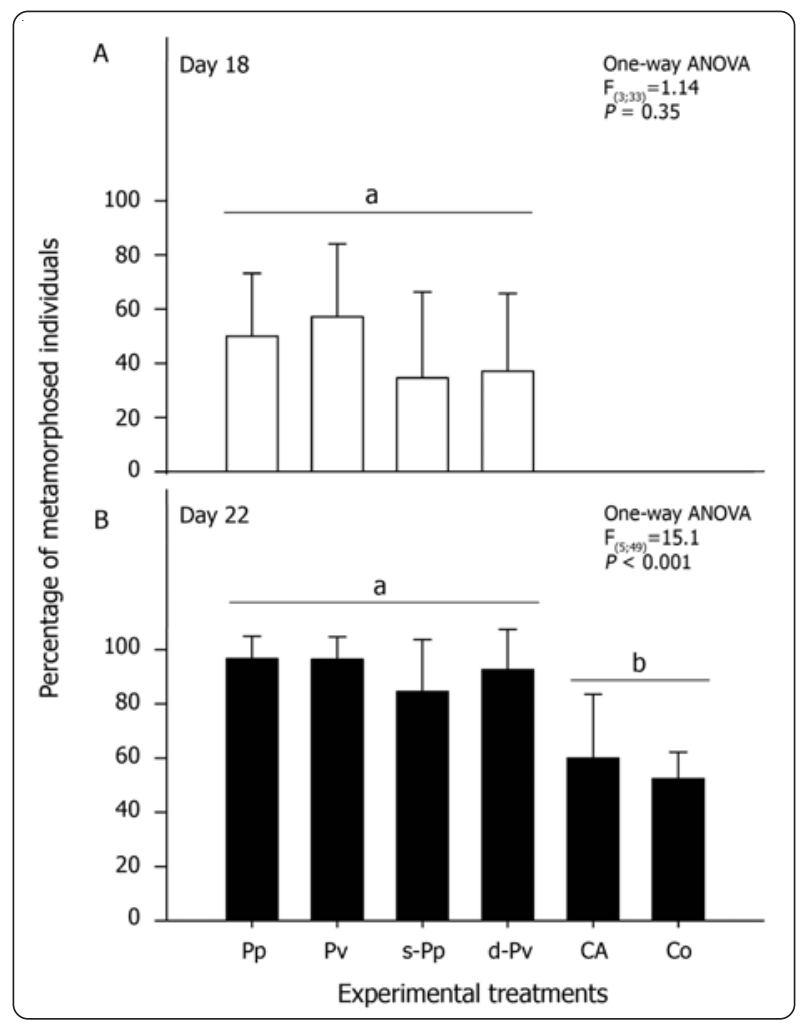

Figure 3. Percentage of metamorphosed larvae (mean \pm standard deviation) in each treatment in two times within of the experiment: A) when $50 \%$ of individuals from the treatment with the most rapid metamorphosis moulting to first juvenile (day 18), and B) when at least half of the individuals had metamorphosed in all treatments (day 22). Abbreviations as in Fig. 1. Lower-case letters indicate statistically significant differences / Porcentaje de larvas metamorfoseadas (promedio \pm desviación estándar) para cada tratamiento en dos momentos dentro del experimento: A) cuando el $50 \%$ de los individuos del tratamiento más rápido mudó a primer juvenil (día 18) y B) cuando al menos la mitad de los individuos metamorfoseó en todos los tratamientos (día 22). Abreviaciones como en la Fig. 1. Las letras minúsculas indican diferencias estadísticamente significativas

larvae), 1200 individuals completed the zoeal stage, the first 540 newly molted megalopae were selected for the experiments.

The duration of the megalopal stage was significantly higher in the control and water incubated with conespecific adults treatments compared to that observed in the other treatments, which on average did not exceed 20 days of development (Fig. 1).

In those treatments that used living individuals of Perumytilus purpuratus and Phragmatopoma virgini as substrates, $50 \%$ of the megalopae had reached metamorphosis at 18 days of development (Fig. 2, 3A). By contrast, in water incubated with conespecific adults 
and the control, half of the larvae had metamorphosed at 20 and 22 days of development, respectively (Fig. 2, 3B), with no metamorphosis having taken place by day 18 of development in this treatments. At 18 days of development, the percentage of metamorphosed larvae exhibited non significant differences between the four treatments with substrates. On the other hand, at 22 days of development, the percentage of metamorphosed individuals was significantly higher in the four experimental treatments with substrates compared to the water incubated with conespecific adults and control treatments (Fig. 3A, B).

Survival varied on average between $22.2 \%$ and $33.3 \%$. At the time at which all existing megalopae metamorphosed to first juvenile, the treatments of water incubated with conespecific adults and control had lower survival rates than the treatments with substrates; however, these differences were not statistically significant (Fig. 4).

\section{Discussion}

Compared with previous results (Barría et al. 2005), the development time and survival of the zoeae were within the range expected under the thermal conditions of this experiment. This indicates that the method of cultivation had no effect on larval ontogeny that might bias the experimental responses. Thus, the results partially support the hypothesis, given that the environmental stimuli tested significantly affected the duration of the megalopa stage, but not the survival of individuals metamorphosed.

All substrates significantly reduced development time, but there were no differential effects caused by using living organisms or their hard structures as metamorphic inductors. This indicates that in A. hassleri, the metamorphosis is not affected by chemical cues from substrates or by conespecific adults. Therefore, under this experimental design, the main metamorphic inducers in the competent larvae of A. hassleri came from the physical characteristics of substrate.

Our results contrast with those reported for other brachyuran species. For example, in the grapsid crab $N$. granulata, the presence of mud in combination with chemical factors from conespecific adults reduced the megalopal development time, accelerating metamorphosis (Gebauer et al. 1998). A similar response was found in $S$. curacaoense, where the metamorphosis was stimulated to varying degrees by factors from chemical substances secreted by conespecific and phylogenetically related species (Gebauer et al. 2002). Both species are gregarious and inhabit muddy marshes, coastal lagoons, and estuaries

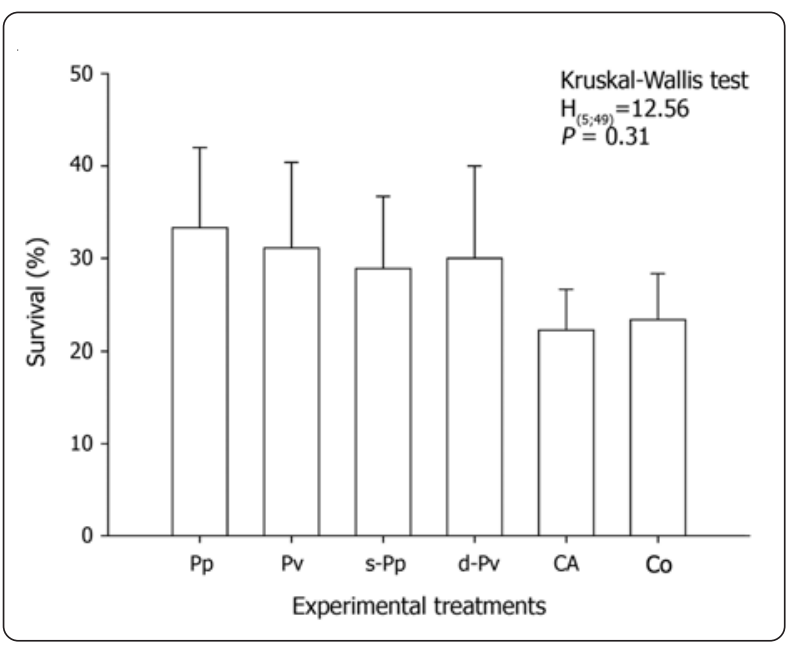

Figure 4. Survival at metamorphosis of $\mathbf{A}$. hassleri megalopae exposed to different treatments designed to induce metamorphosis. Abbreviations as in Fig. 1 / Supervivencia en la metamorfosis de las megalopas de A. hassleri expuestas a diferentes tratamientos de inducción a la metamorfosis. Abreviaciones como en la Fig. 1

in the case of N. granulata (Boschi 1964, Spivak 2010) and the shallow waters of mangroves in the case of $S$. curacaoense (Abele 1992). These environments are characterized by low energy hydrographic dynamics, as they are mainly influenced by tidal regimes (Hayes 1979). On the other hand, the Acanthocyclus genus recruits in the intertidal zone of exposed rocky shores (Jara \& Moreno 1983, Castilla et al. 1989), whose dynamics are influenced by wave action and high velocity energetic current. This creates a heterogeneous mosaic of hydrodynamic conditions that influence the patterns of coastal advection of benthic invertebrate larvae (Palma et al. 2006). Under these conditions, the textural and microtopographic heterogeneity of the substrate may be more relevant in inducing settlement and metamorphosis, providing the megalopae with adequate conditions for grip and protection against the environmental stress provoked by the highly dynamic hydrography of the open coast. Additionally, the stimulation of settlement and metamorphosis by conespecific cues, and the consequent delay of such events by the absence of the stimuli have been documented for gregarious species (Jensen 1989, 1991, Gebauer et al. 2003). However, populations of A. hassleri are not gregarious, displaying interference and territorial behaviours that restrict their adult population density (Navarrete \& Castilla 1990, Navarrete et al. 2008). The integration of these responses allows us to infer that the nature (physical, chemical and/or biological) of the cues 
inducing settlement and metamorphosis in decapod crustaceans depends largely on the characteristics of the habitat and demographics of the adult populations.

The cumulative frequency curves of metamorphosed individuals exhibited similar patterns of responses for treatments with substrates, but significantly different curves for the control and the water from conespecific adults treatments. On day 22 of development, intra-group variation was closer and the differences between treatments were less than on day 18 (Fig. 3). This indicates that under the culture condition of the present experiment, the megalopa of A. hassleri had a window of receptivity to the stimulation of metamorphosis of four days on average. If in this period, the larva could not find the adequate stimulus, a spontaneous metamorphosis occurred. This phenomenon has also been observed in other brachyuran species but with windows of receptivity of greater duration (Gebauer et al. 1998, 2002, 2004, 2005). Previous experiences with larval development in A. hassleri indicates that the optimal development of the megalopa occurs at $17^{\circ} \mathrm{C}$ (Barría et al. 2005), higher than the temperature used in this experiment $\left(12^{\circ} \mathrm{C}\right)$. Consequently, it is expected that the megalopae near their thermic optimum accelerate their development time and thus reduce their window of receptivity. However, considering that the exposed rocky intertidal environments are structurally heterogeneous, and the metamorphosis of A. hassleri was mainly influenced by the physiognomy of the substrate, the probability that competent larvae will find the necessary support and shelter conditions in these environments seems to be quite high.

The survival of the megalopa was low and independent of experimental treatment. Drastic declines in the survival of this stage have been reported previously for this species and for other brachyuran crabs e.g., Cancer magister and N. granulata (Sulkin \& McKeen 1996, Ismael et al. 1997, Barría et al. 2005). In general, high mortality at the megalopa stage has been attributed to increased sensitivity to environmental changes, due to the metamorphosis and pelagic-benthic transition having implicit important physiological changes such as reduced metabolism, primarily by lower respiration, feeding, and growth rates (Anger 2001). However, it should be noted that in all cases, including the present study, the megalopae culture conditions maybe nutritionally deficient as Artemia sp. nauplii are not the best possible food. Although this has not been experimentally tested, it is possible that the culture conditions could have a significant degree of responsibility in the mortality, acting as an experimental artefact.

From this study we concludes that: 1) the duration of the megalopa stage in A. hassleri is a plastic trait strongly influenced by the presence or absence of a suitable substrate; 2) certain physical properties of the substrate such as surface texture or topography may be more important in inducing settlement and metamorphosis that any chemical cue; 3 ) the absence of a suitable substrate is not a critical factor that affects the mortality, because the competent larvae are capable of spontaneous metamorphosis. Comparing the results of this study with previous reports on other brachyuran crabs, it is possible to postulate that there are species-specific associations between the type of stimuli that induce metamorphosis, population attributes and habitat characteristics. However, additional case studies are required in order to establish cause and effect relationships within these correlational patterns.

\section{Aknowledgments}

Study partially funded by DID-E-97-03 and DID-S-98-17 from the Dirección de Investigacion y Desarrollo; Universidad Austral de Chile. The first author has been supported by the MECESUP AUS 0111 and CONICYT doctoral fellowships programs. We appreciate the comments and suggestions from Dr. Matthew Lee (Universidad Austral de Chile) and two anonymous reviewers who helped to improve the content of this article.

\section{LITERATURE CITED}

Abele LG. 1992. A review of the grapsid crab Genus Sesarma (Crustacea: Decapoda: Grapsidae) in America, with the description of a new genus. Smithsonian Contributions to Zoology 527: 1-60.

Anger K. 1987. The $\mathrm{D}_{0}$ threshold: a critical point in the larval development of decapod crustaceans. Journal of Experimental Marine Biology and Ecology 108: 15-30.

Anger K. 2001. The biology of decapod crustacean larvae. Crustacean Issues 14: 1-405. A.A. Balkema, Lisse.

Barría EM, CG Jara \& KA Paschke. 2005. La temperatura como factor de variabilidad en el desarrollo y morfología de larvas zoeas de Acanthocyclus hassleri Rathbun (Decapoda, Brachyura, Atelecyclidae) cultivadas en laboratorio. Investigaciones Marinas 33(1): 25-41.

Boschi EE. 1964. Los crustáceos decápodos Brachyura del litoral bonaerense (R. Argentina). Boletín del Instituto de Biología Marina, Mar del Plata 6: 1-99.

Brown MB \& AB Forsythe. 1974. Robust tests for the equality of variances. Journal of the American Statistical Association 69(346): 364-367. 
Carrasco RA \& JH Zamorano. 2000. Fecundidad y período reproductivo en poblaciones simpátricas de Acanthocyclus gayi Milne Edwards \& Lucas, 1844 y A. hassleri Rathbun, 1898 (Decapoda: Atelecyclidae), en el intermareal rocoso de Pichicullín ( $\mathrm{X}^{\mathrm{a}}$ Región, Chile). Revista de Biología Marina y Oceanografía 35(1): 103-110.

Castilla JC, C Luxoro \& SA Navarrete. 1989. Galleries of the crabs Acanthocyclus under intertidal mussel beds: their effects on the use of primary substratum. Revista Chilena de Historia Natural 62: 199-204.

Chia FS. 1978. Perspectives: settlement and metamorphosis of marine invertebrate larvae. In: Chia FS \& ME Rice (eds). Settlement and metamorphosis of marine invertebrate larvae, pp. 283-285. Elsevier, New York.

Christy JH. 1989. Rapid development of megalopae of the fiddler crab Uca pugilator reared over sediment: implications for models of larval recruitment. Marine Ecology Progress Series 57: 259-265.

Forward RB Jr, RA Tankersley, D Blondel \& D Rittschof. 1997. Metamorphosis of the blue crab Callinectes sapidus: effects of humic acids and ammonium. Marine Ecology Progress Series 157: 277-286.

Gebauer P, I Walter \& K Anger. 1998. Effects of substratum and conspecific adults on the metamorphosis of Chasmagnathus granulata (Dana) (Decapoda: Grapsidae) megalopae. Journal of Experimental Marine Biology and Ecology 223: 185-198.

Gebauer P, K Paschke \& K Anger. 2002. Metamorphosis in a semiterrestrial crab, Sesarma curacaoense: intra- and interspecific settlement cues from adult odors. Journal of Experimental Marine Biology and Ecology 268: 1-12.

Gebauer P, K Paschke \& K Anger. 2003. Delayed metamorphosis in decapod crustaceans: evidence and consequences. Revista Chilena de Historia Natural 76: 169175.

Gebauer P, K Paschke \& K Anger. 2004. Stimulation of metamorphosis in an estuarine crab, Chasmagnathus granulata (Dana, 1851): Temporal window of cue receptivity. Journal of Experimental Marine Biology and Ecology 311: 25-36.

Gebauer P, K Paschke \& K Anger. 2005. Temporal window of receptivity and intraspecific variability in the responsiveness to metamorphosis-stimulating cues in the megalopa of a semi-terrestrial crab Sesarma curacaoense. Invertebrate Reproduction and Development 47: 39-50.

Gill JL. 1978. Design and analysis of experiments in the animal and medical sciences, 409 pp. Iowa State University Press, Iowa.

Hadfield MG. 1986. Settlement and recruitment of marine invertebrates: a perspective and some proposals. Bulletin of Marine Science 39(2): 418-425.

Hadfield MG. 2000. Why and how marine invertebrate larvae metamorphose so fast. Seminars in Cell and Developmental Biology 11(6): 437-443.
Hadfield MG, EJ Carpizo-Ituarte, K Del Carmen \& BT Nedved. 2001. Metamorphic competence, a major adaptive convergence in marine invertebrate larvae. American Zoologist 41: 1123-1131.

Hayes MO. 1979. Barrier island morphology as a function of tidal and wave regime. In: Leatherman M (ed). Barrier Island, pp. 1-27. Academic Press, San Diego.

Hurlbut CJ. 1991. Community recruitment: settlement and juvenile survival of seven co-occurring species of sessile marine invertebrates. Marine Biology 109: 507-515.

Ismael D, K Anger \& GS Moreira. 1997. Influence of temperature on larval survival, development, and respiration in Chasmagnathus granulata (Crustacea, Decapoda). Helgolander Meeresuntersuchungen 51: 463475.

Jara F \& CA Moreno. 1983. Calendario de reclutamiento de organismos epibénticos móviles de la zona mesomareal de Mehuín. Medio Ambiente, Chile 6: 72-79.

Jensen GC. 1989. Gregarious settlement by megalopae of the crabs Petrolisthes cinctipes (Randall) and P. eriomerus (Stimpson). Journal of Experimental Marine Biology and Ecology 131: 223-231

Jensen GC. 1991. Competency, settling behavior, and postsettlement aggregation by porcelain crab megalopae (Anomura: Porcellanidae). Journal of Experimental Marine Biology and Ecology 153: 49-61.

Lincoln R, G Boxshall \& P Clark. 1998. A dictionary of ecology, evolution and systematic, $257 \mathrm{pp}$. Cambridge University Press, Cambridge.

McConaugha JR. 1992. Decapod larvae: Dispersal, mortality and ecology. A working hypothesis. American Zoologist 32(3): 512-533.

Navarrete SA \& JC Castilla. 1990. Resource partitioning between intertidal predatory crabs: interference and refuge utilization. Journal of Experimental Marine Biology and Ecology 143: 101-129.

Navarrete SA, M Parragué \& EA Wieters. 2008. Local and meso-scale patterns of recruitment and abundance of two intertidal crab species that compete for refuges. Marine Biology 155: 223-232.

O’Connor NJ \& AS Gregg. 1998. Influence of potencial habitat cues on duration of the megalopal stage of the fiddler crab Uca pugnax. Journal of Crustacean Biology 18(4): 700-709.

Olson RR \& MH Olson. 1989. Food limitation of planktotrophic marine invertebrate larvae: does it control recruitment success? Annual Review of Ecology and Systematics 20: 199-223.

Palma AT, LM Pardo, R Veas, C Cartes, M Silva, K Manríquez, A Díaz, C Muñoz \& FP Ojeda. 2006. Coastal brachyurans decapods: settlement and recruitment under contrasting coastal geometry conditions. Marine Ecology Progress Series 316: 139-153. 
Pardo LM, AT Palma, C Prieto, P Sepúlveda, I Valdivia \& FP Ojeda. 2007. Processes regulating early post-settlement habitat use in a subtidal assemblage of brachyuran decapods. Journal of Experimental Marine Biology and Ecology 344: 10-22.

Pawlik JR. 1998. Coral reef sponges: Do predatory fishes affect their distribution? American Society of Limnology and Oceanography 43(6): 1396-1399.

Pechenik JA. 2006. Larval experience and latent effects metamorphosis is not a new beginning. Integrative and Comparative Biology 46(3): 323-333.

Pechenik JA, D Wendt \& JN Jarrett. 1998. Metamorphosis is not a new beginning. Larval experience influences juvenile performance. BioScience 48: 901-910.

Prado L \& JC Castilla. 2006. The bioengineer Perumytilus purpuratus (Mollusca: Bivalvia) in central Chile: biodiversity, habitat structural, complexity and environmental heterogeneity. Journal of the Marine Biological Association of the United Kingdom 86(2): 417421.

Retamal M. 1981. Catálogo ilustrado de los crustáceos decápodos de Chile. Gayana Zoología 44: 1-110.

Rodríguez SR, FP Ojeda FP \& NC Inestrosa. 1993. Settlement of benthic marine invertebrates. Marine Ecology Progress Series 97: 193-207.

Roegner GC. 1991. Temporal analysis of the relationship between settlers and recruits of the oysters Crassostrea virginica (Gmelin). Journal of Experimental Marine Biology and Ecology 151: 57-69.
Sepúlveda RD, RA Moreno \& FD Carrasco. 2003. Diversidad de macroinvertebrados asociados a arrecifes de Phragmatopoma moerchi Kinberg, 1867 (Polychaeta: Sabellariidae) en el intermareal rocoso de Cocholgüe, Chile. Gayana Zoología 67(1): 45-54.

Spivak E. 2010. The crab Neohelice (=Chasmagnathus) granulata: an emergent animal model from emergent countries. Helgoland Marine Research 64(3): 149-154. <doi: 10.1007/s10152-010-0198-z>

Sulkin SD \& GL McKeen. 1996. Larval development of the crab Cancer magister in temperature regimes simulating outer-coast and inland-water habitats. Marine Biology 127: 235-240.

Wehrtmann IS \& GA López. 2003. Effects of temperature on the embryonic development and hatchling size of Betaeus emarginatus (Decapoda: Caridea: Alpheidae). Journal of Natural History 37: 2165-2178.

Williamson DI. 1969. Names of larvae in the decapoda and euphausiacea. Crustaceana 16(2): 210-213.

Zagal C, C Hermosilla \& A Riedemann. 2001. Guía de invertebrados marinos del litoral valdiviano, $215 \mathrm{pp}$. Universidad Austral de Chile, Valdivia.

Zamorano JH, CA Moreno \& WE Duarte. 1995. Postsettlement mortality in Phragmatopoma virgini (Polychaeta: Sabellariidae) at the Mehuin Marine Reserve, Chile. Marine Ecology Progress Series 127: 149-155.

Zar J. 1999. Biostatistical analysis, 663 pp. Prentice Hall, Englewood Cliff.

Recibido el 27 de junio de 2010 y aceptado el 30 de julio de 2010 